\title{
Physicochemical and biological characterization of the Roble river, Upper Cauca, western Colombia
}

\author{
Carlos A. GARCÍA-ALZATE ${ }^{1}$, Cesar ROMÁN-VALENCIA ${ }^{1}$, Donald C. TAPHORN ${ }^{2}$ \\ \& Melissa I. GONZALEZ ${ }^{1}$
}

\author{
${ }^{1}$ Ichthyology Lab, Biology Program, University of Quindío, A.A. 2639, Armenia, Colombia; \\ cagarcia@uniquindio.edu.co. ${ }^{2} 1822$ N. Charles St., Belleville, IL, 62221 USA; taphorn@gmail.com
}

\begin{abstract}
Caracterización fisicoquímica y biológica del río Roble, Alto Cauca, occidente de Colombia. Para determinar las diferencias diarias y estaciónales, así como la productividad y el estado trófico del río Roble, un afluente de la Vieja, alto Cauca al occidente de Colombia, tomamos muestras de fitoplancton, zooplancton, peces y macroinvertebrados y registramos variables físico-químicas (oxígeno disuelto, porcentaje de saturación de oxígeno, $\mathrm{pH}$, conductividad, humedad relativa, temperaturas ambiente, del agua, máximas y mínimas, ancho, profundidad, velocidad de la corriente, sustrato, $\mathrm{CO}_{2}, \mathrm{DQO}, \mathrm{DBO}_{5}$, dureza total, dureza calcica y durezas magnesicas, sólidos totales, disueltos y suspendidos, alcalinidad, acidez, cloruros y turbidez) durante sequía y lluvias. La mayoría de las variables físico-químicas tales como la humedad relativa, oxígeno disuelto y porcentaje de saturación de oxígeno mostraron bajos coeficientes de variación, a excepción de déficit de oxígeno. El índice de diversidad de Shannon-Wiener, Equidad y Dominancia fueron bajos alrededor de 0.5. Registramos ocho órdenes, 28 familias y 58 géneros de macroinvertebrados, tres divisiones, cinco órdenes y 45 géneros de fitoplancton, dos divisiones y seis géneros de zooplancton y 19 especies de peces. El río Roble presentó un estado trófico heterotrófico-alóctono y es oligotrófico con tendencia a la eutroficación.
\end{abstract}

Key words: Estado trófico, limnología, bioindicadores, quebrada, metabolismo.

Resumen: To determine dial and seasonal differences as well as productivity and the trophic status of the lower Roble river, a tributary of the Vieja and upper Cauca rivers of west Colombia, we sampled phytoplankton, zooplankton, fish and macroinvertebrates and recorded physicochemical variables (dissolved oxygen, percent oxygen saturation, $\mathrm{pH}$, conductivity, relative humidity, temperatures environmental, water, maximum and minimum, width, depth, current velocity, substrate, $\mathrm{CO}_{2}, \mathrm{COD}, \mathrm{BOD}$, total hardness, calcium and magnesium, total solids, dissolved and suspended, alkalinity, acidity, chlorine and turbidity) during the wet and dry seasons. Most physicochemical variables such as relative humidity, dissolved oxygen and percent oxygen saturation showed low coefficients of variation, except for oxygen deficit. The Shannon-Wiener diversity index, equity and dominance had low values around 0.5. We recorded eight orders, 28 families and 58 genera of macroinvertebrates, three divisions, five orders and 45 genera of phytoplankton, two divisions and six genera of zooplankton and 19 species of fishes. This river has an allochthonous-heterotrophic trophic state and productivity is oligotrophic but with a tendency to eutrophication.

Palabras clave: Trophic state, limnology, bioindicators, stream, metabolism.

\section{INTRODUCTION}

Limnological studies show that most water bodies today are impacted by human activities. In the Neotropics, significant degradation of aquatic resources occurs because of agriculture and residual water from households (Román-Valencia et $a l ., 2005)$. Limnological analyses are usually carried out to determine baseline vales for physical and chemical characteristics of water bodies and how these correlate with the associated biological communities. It has been shown that each type of aquatic ecosystem is usually associated with a particular community of organisms (Lampert \& Sommer, 1997, Wetzel \& Likens, 2000; Roldan \&
Ramirez, 2008). Biological aspects of aquatic ecosystems have become increasingly important in monitoring their health because physicochemical variables only provide a snapshot in time of water quality, but do not represent how the ecosystem changes over time (Alba-Tercedor, 1996). The living elements of these systems, such as macroinvertebrates, fish, phytoplankton and zooplankton are witnesses to the environmental degradation of surface waters where they live. (Caicedo \& Palacio, 1998). As such, changes in the abundance and structure of their communities, when compared within hydrological systems of similar characteristics, act as biological indicators of aquatic ecosystem overall health. 
In the Neotropics, natural dramatic altitudinal and seasonal differences have been documented for physical and chemical parameters of continental waters (rivers, streams, lakes) (Sierra et al., 2004). But constantly increasing anthropogenic impacts are rapidly overshadowing naturally occurring variations in freshwater ecosystems. The objective of this study provide baseline data on the aquatic ecosystem health of the lower Roble river, Vieja river drainage, upper Cauca, Colombia. By measuring both physicochemical and biological variables we provide a comparison point for future studies.

\section{MATERIALS AND METHODS}

Study area. The Roble river is located in the Colombian department of Quindío, and includes the Quimbaya and Montenegro municipalities (N $\left.4^{\circ} 40^{\prime} 74^{\prime \prime}-\mathrm{W} 75^{\circ} 53^{\prime} 64^{\prime \prime}\right)$, at an elevation of about 1100 m.a.s.l. The vegetation in this region is represented by the families of Asteraceae, Zingiberaceae, Mirtaceae, Curcurbitaceae, Cyperaceae, Heliconeacea, Piperaceae, Marantaceae, Amarantaceae, Moraceae, Cecropiaceae, Leguminosae, Melastometaceae and Poaceae; and is dominated by bamboo Guadua angustifolia and ferns (Pteridophyta). This type of vegetation is characteristic of premontane humid forests. Water color is brown, and the substrate is a mix of stones and sand. In some places of lower velocity of water flow, organic detritus accumulates.

Sampling and laboratory analyses. Samples were collected from 29 February - 2 March and from 17- 19 April 2008. Average multi-annual precipitation (1985-2005) was determined from pluviometric data from the Maracay meteorological station ( $4^{\circ} 36^{\prime}-\mathrm{W} 75^{\circ} 44^{\prime}, 1402$ $\mathrm{m}$.a.s.l.). dissolved oxygen, percentage of oxygen saturation and water temperature were recorded with a digital oxymeter OXI196-microprocessor; $\mathrm{pH}$ with a potentiometer PIN POINT-BNC, conductivity with conductimeter (Hanna H198842); relative humidity, ambient temperature, maximum and minimum temperature with a digital thermohygrometer (Fisher Scientific W5160H); width and depth with a decameter and flexometer respectively and current velocity was measured by timing a floating ball in to travel one meter.

Water samples were analyzed in the water laboratory of Quindío University for total hardness, calcium and magnesium hardness, total solids, dissolved and suspended solids, alkalinity, acidity, chlorine and turbidity using the methods described in APHA (1998) and Wetzel \& Linkens (2000). Phytoplankton and zooplankton were collected in one liter bottles, preserved in

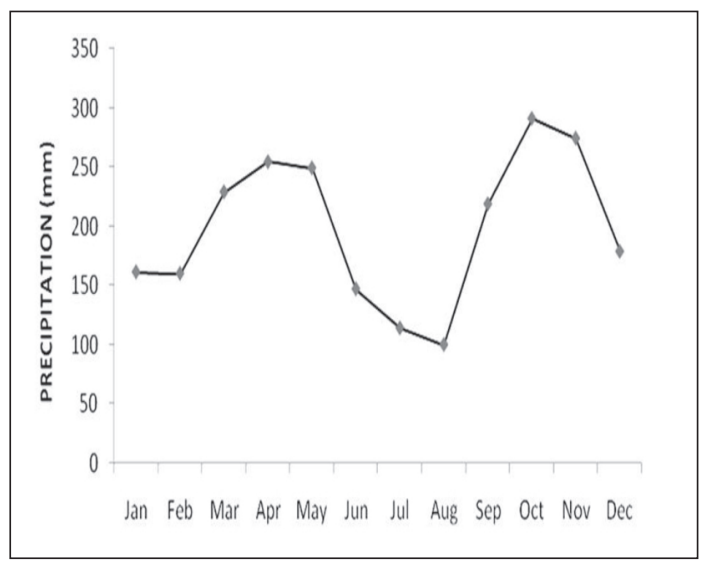

Fig. 1. Pluviometric data of station Quimbaya, Maracay, Department of Quindío, Colombia. This data are on average precipitation between 1985 and 2005 for station Maracay.

situ with $4 \%$-formaldehyde, stained with lugol and later transported to the Biology Laboratory of Quindío University for identification by using taxonomic keys Lackey (1956), Kudo (1966), Bicudo \& Bicudo (1970), Uhlerkovich \& Schmidt (1974), Needham \& Needham (1978). Phytoplankton and zooplankton density was determined using the drop technique and expressed as ind $/ \mathrm{ml}$. Macroinvertebrates were collected with the use of hand nets, surber nets, triangular nets (D-net) and entomological forceps (direct capture), and were preserved in 70\%-alcohol and transported to the laboratory for identification to genus with taxonomic keys: Rodriguez et al. (1992), Roldan (1996), Wetzel \& Linkens (2000), and Posada-García \& Roldan-Pérez (2003). Fishes were collected with different kinds of nets following methodology of García-Alzate et al. (2007). When possible, identification was done in situ but samples that couldn't be determined in the field visually were preserved in $10 \%$-formaldehyde and taken to the Ichthyology Laboratory at Quindío University where they were identified using taxonomic keys for this area (Román-Valencia 1995, 2003; Ruiz-Calderon \& Román-Valencia 2006; Román-Valencia \& Ruiz-Calderon 2007; García-Alzate \& Román-Valencia 2008).

Metabolism. Ecosystem metabolism (Wetzel \& Likens, 2000) was calculated by collecting water samples at regular intervals during 40 hours and determining dissolved oxygen, percent oxygen saturation, $\mathrm{pH}$ and conductivity in transparent and dark bottles.

Data analysis. For pluviometric data the multi-annual monthly analysis was made with averages from 1985 to 2005 from the Maracay station. Analysis of variance (ANOVA) was cal- 


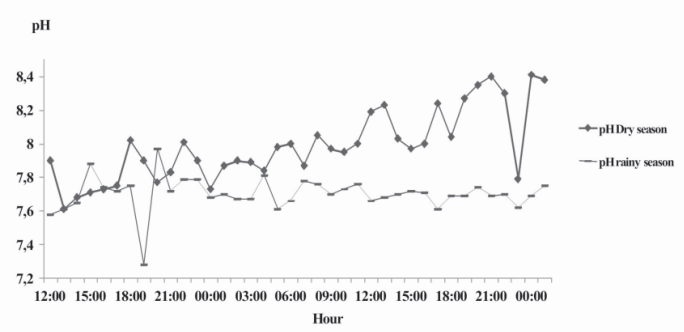

C

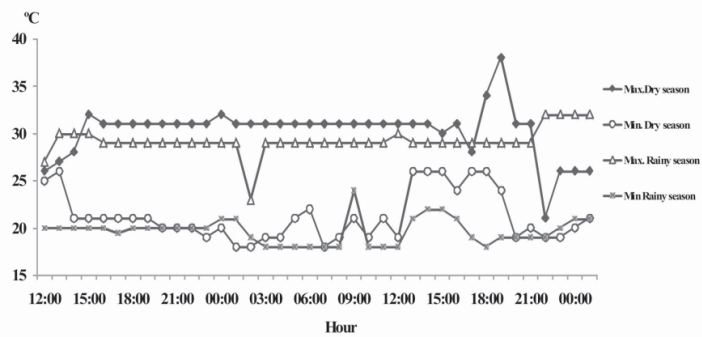

B

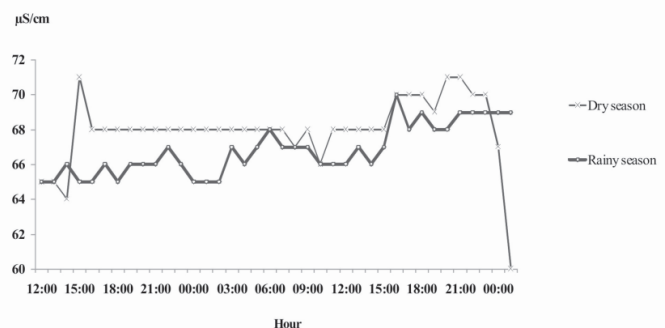

D

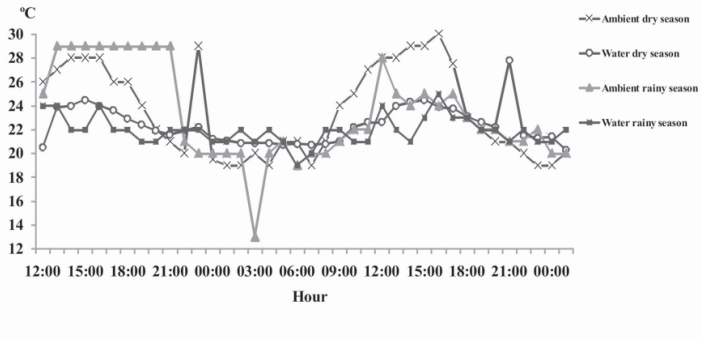

Fig. 2. Comparison of nictemeral compartment, of physicochemical variables in Roble river, Upper Cauca Colombia; (A.) $\mathrm{pH}$, in dry and rainy season; (B.) conductivity in dry and rainy season; (C.) Maximal and minimal temperature in dry and rainy season; (D.) Water temperature and ambient temperature in dry and rain.

culated with $95 \%$ significance for comparison of physicochemical variables between seasons and hours. Also the coefficient of variation (CV) was calculated as an average of relative dispersion that indicates the relationship between the standard deviation and the average, and range (maximum and minimum values) by using the statistic package Stat graphics Plus 5.1. Index of water quality was calculated following Viña \& Ramirez (1998). Dissolved oxygen was corrected for altitude (Roldan, 1992). Oxygen deficit was calculated comparing values of dissolved oxygen from the river with those of the transparent and dark bottles between season (Wetzel \& Likens, 2000). Relative and absolute abundance were calculated from biological variables such as the Shannon-Wiener index of diversity (H'), Margalef (M), Simpson dominance (D) and Pielou equity (E) using Divers under Windows program (Pérez \& Sola, 1993) with index of logarithm in base 10. The BMWP index for macroinvertebrates modified for Colombia was calculated (BMWP/Col; Roldan, 2003).

\section{RESULTS}

Physicochemical variables. Twenty years of records from the Maracay station, Quimbaya municipality, show an annual bimodal rainfall distribution with peaks in April-May, and October-November. Our sampling times thus include both the dry and rainy seasons (Fig. 1).
Physicochemical parameters showed significant differences between seasons, except for minimum temperature $(\mathrm{F}=1.95, \mathrm{p}=0.512)$. Dial variation for most physical and chemical variables didn't show significant differences except conductivity in the rainy season $(\mathrm{F}=3.47, \mathrm{p}=$ 0.001). Maximum and minimum temperature both noticeably decreased at night (Fig. 2c), ANOVA showed that significant differences exist between maximum and minimum temperatures for the different seasons $(\mathrm{F}=24.47$, $\mathrm{p}=0.000)$. Coefficients of variation $(\% \mathrm{CV})$ of maximum and minimum temperature for dry and rainy season were generally low (Table 1 ).

The $\mathrm{pH}$ values (Fig. 2a) differed significantly between seasons $(\mathrm{F}=1.79 ; \mathrm{p}=0.032)$ but for the dial cycle it varied little $(3.27 \% \mathrm{CV}$ in dry and $2.77 \% \mathrm{CV}$ in rainy season), generally $\mathrm{pH}$ values were close to neutral. Conductivity also showed a low coefficient of variation $(3.08 \% \mathrm{CV}$ in rainy and $2.18 \%$ C.V in dry season), and the mode was the same for both seasons $(67 \mu \mathrm{s} / \mathrm{cm})$. Nevertheless, ANOVA showed that significant differences did exist between seasons $(F=5.32 ; p=0.000)$, with atypical values in the dry season, whereas for the rainy season records were more homogeneous with little noticeable variation (Fig. 2c). Average water temperature was $22.32{ }^{\circ} \mathrm{C}$; the dry season coefficient of variation was low $(6.94 \%$ C.V), and the rainy season average was lower $\left(21.86^{\circ} \mathrm{C}\right)$ with the same as coefficient of varia- 
TABLE 1. Physicochemical variables of the Roble river, Upper Cauca, Colombia. $\boldsymbol{C} . \boldsymbol{V}=$ Coefficient of variation.

\begin{tabular}{|c|c|c|c|c|}
\hline \multirow[t]{2}{*}{ VARIABLES } & \multicolumn{2}{|l|}{ DRY SEASON } & \multicolumn{2}{|l|}{ RAINY SEASON } \\
\hline & VALUE & C.V (\%) & VALUE & C.V $(\%)$ \\
\hline Altitude (m.a.s.l) & 1100 & & & \\
\hline Water temperature $\left({ }^{\circ} \mathrm{C}\right)$ & $20.3-24.5(22.32 \pm 1.54)$ & 6.94 & $19-24(21.86 \pm 1.13)$ & 1.10 \\
\hline Ambient temperature $\left({ }^{\circ} \mathrm{C}\right)$ & $19-29(23.682 \pm 3.64)$ & 15.4 & $13-29(22.95 \pm 3.77)$ & 5.20 \\
\hline Oxygen saturation (\%) & $39.6-107(69.28 \pm 20.30)$ & 29.30 & $39,9-97,65(68,06)$ & 21,49 \\
\hline Dissolved oxygen mg/L & $3.81-8.775(6.23 \pm 1.72)$ & 27.60 & $3,26-7,8(5,33)$ & 18,32 \\
\hline Relative humidity & $41-97(74.07 \pm 20.88)$ & 28.18 & $42-93(85.52 \pm 11.6)$ & 13.62 \\
\hline $\mathrm{pH}$ & $7.16-8.41(7.94 \pm 0.36)$ & 3.27 & $7.2-8.38(7.75 \pm 0.21)$ & 2.77 \\
\hline Conductivity & $60-71(67.77 \pm 2.09)$ & 3.08 & $65-69(67 \pm 1.46)$ & 2.18 \\
\hline Maximum temperature $\left({ }^{\circ} \mathrm{C}\right)$ & $21-38(29.77 \pm 2.85)$ & 15.42 & $21-30(28.56 \pm 2.78)$ & 9.74 \\
\hline Minimum temperature $\left({ }^{\circ} \mathrm{C}\right)$ & $18-26(21.25 \pm 2.52)$ & 11.89 & $16-24(19.67 \pm 1.47)$ & 7.48 \\
\hline O.D. & 6.53 & - & 6.0 & - \\
\hline D.B.O mg/ $/ \mathrm{O}_{2}$ & 3.1 & - & 5.2 & - \\
\hline D.Q.O mg/l O & 183.92 & - & 80 & - \\
\hline Total hardness $\left(\mathrm{mg} / \mathrm{l} \mathrm{CaCO}_{3}\right)$ & 32 & - & 26 & - \\
\hline Calcium hardness $\left(\mathrm{mg} / \mathrm{l} \mathrm{CaCO}_{3}\right)$ & 12 & - & 16 & - \\
\hline Magnesium hardness mg/l $\mathrm{CaCO}_{3}$ & 20 & - & 10 & - \\
\hline Alkalinity $(\mathrm{mg} / \mathrm{l} \mathrm{CaCO})_{3}$ & 64.28 & - & 28.14 & - \\
\hline Acidity $\left(\mathrm{mg} / \mathrm{l} \mathrm{CaCO}_{3}\right)$ & 37.16 & - & 15.9 & - \\
\hline Total solids $\mathrm{mg} / \mathrm{l}$ & 120 & - & - & - \\
\hline Dissolved solids & 80 & - & - & - \\
\hline Suspended solids mg/l & 40 & - & 5.0 & - \\
\hline Chlorine mg/l & 84.09 & - & 4.50 & - \\
\hline Turbidity & 129 F.T.U & - & $<5$ F.T.U & - \\
\hline Discharge $\left(\mathrm{m}^{3} / \mathrm{s}\right)$ & 343.56 & & & \\
\hline $\mathrm{CO}_{2}$ & 3.645 & - & 3.645 & - \\
\hline Fecal Coliform UFC/100ml & 100 & - & - & \\
\hline Total Coliform UFC/100ml & 120 & - & - & \\
\hline Substrate & Stony & & Stony - Sandy & \\
\hline Width (m) & 16.33 & - & 18 & \\
\hline Depth (m) & 1.2 & - & 1.4 & \\
\hline Color & Brown & & Brown & \\
\hline Velocity of current $\mathrm{m} / \mathrm{s}$. & $0.018-0.025(0.22)$ & - & 2.016 & - \\
\hline TRANSPARENT BOTTLE & & & & \\
\hline Dissolved oxygen mg/l & $3.4-9.71(6.07 \pm 1.74)$ & 28.71 & $2,98-8,3(5,21)$ & 21,51 \\
\hline Oxygen saturation (\%) & $37.3-107(66.34 \pm 21.69)$ & 32.69 & $36,75-100,8(63,57)$ & 18,05 \\
\hline Oxygen deficit mg/l & $-2.57-3.65(1.057)$ & 167.19 & $-3-2,3(0,08)$ & 100,78 \\
\hline $\mathrm{pH}$ & - & - & $7.2-8.38(7.75 \pm 0.21)$ & 2.77 \\
\hline Conductivity & - & - & $65-69(67 \pm 1.46)$ & 2.18 \\
\hline DARK BOTTLE & & & & \\
\hline Dissolved oxygen mg/l & $3.05-9.5(6.13 \pm 1.73)$ & 28.2 & $2,61-8,2(5,24)$ & 20,50 \\
\hline Oxygen saturation (\%) & $36.1-107(67.26 \pm 19.68)$ & 29.26 & $30,45-102,9(64,18)$ & 17,98 \\
\hline Oxygen deficit & $-1.83-4.66(1.58)$ & 110.71 & $-2,5-2,7(0,10)$ & 100,86 \\
\hline $\mathrm{pH}$ & - & - & $7.2-8.46(7.68 \pm 0.22)$ & 2.46 \\
\hline Conductivity & - & - & $65-80(68.90 \pm 2.54)$ & 2.69 \\
\hline
\end{tabular}

tion $(1.10 \%)$ although this was considered low it was observed that for this period data was close to an average, and that explains differences in the coefficient of variation for both seasons (Fig. $2 d$ ). Generally in both climatic seasons temperature decreased if we take into consideration maximum and minimum registered values (Table 1 ). ANOVA showed that water and ambient temperature had significant differences between seasons $(\mathrm{F}=9.45, \mathrm{p}=0.000 ; \mathrm{F}=2.31, \mathrm{p}=0.01)$.

ANOVA showed significant differences in relative humidity between seasons $(\mathrm{F}=10.76$; $\mathrm{p}=0.000$ ); for the dial cycle this variable had a high coefficient of variation $(28.18 \%$ ) with mode of $74.07 \%$ for dry season, very different from the rainy season where the coefficient of variation was low (CV 13.62), with an average of $85.52 \%$. Nevertheless, in the dry season this variable showed higher fluctuations compared with the rainy season (Fig. 3a).

Dissolved oxygen was generally high in the dry season with an average of $6.23 \mathrm{mg} / \mathrm{l}$ and a high coefficient of variation (27.60\%) in comparison with rainy season $(5,32 \mathrm{mg} / \mathrm{l}$ and $18,32 \%)$. 
A

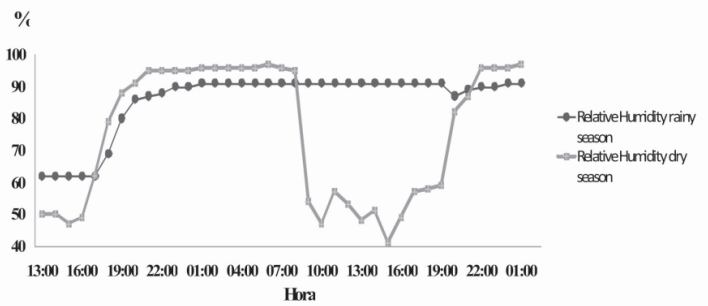

Hora

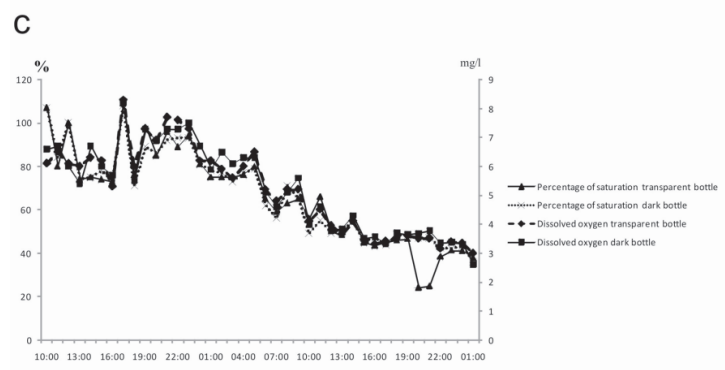

B
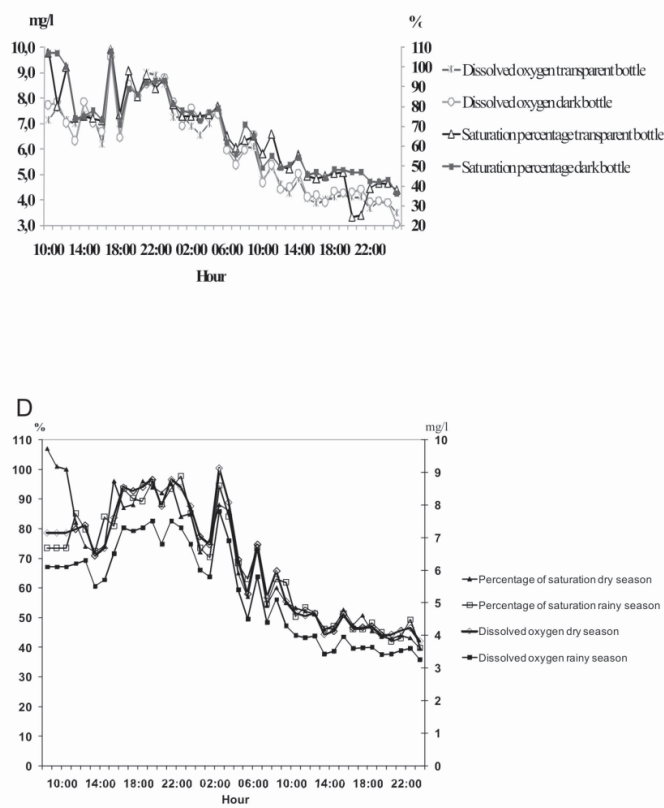

Fig. 3. Comparison of nictemeral compartment, physicochemical variables in Roble river; (A.) Relative humidity, in rainy and dry season; (B.) Dissolved oxygen and percentage of oxygen saturation in transparent and dark bottle, in dry season; (C.) Dissolved oxygen and percentage of oxygen saturation in transparent and dark bottle, in rainy season; (D.) Percentage of oxygen saturation and dissolved oxygen in dry and rainy season in the Roble river.

The same was true for percent oxygen saturation with an average of $69.28 \%$ and a high coefficient of variation in the dry season $(29.30 \%)$ in comparison with rainy season $(68,03 \%$ and $21,49 \%$ ). Nevertheless, values of dissolved oxygen were closer to the average than the values of oxygen saturation for both seasons (Table 1). It was also observed that both of these variables decreased significantly on the second day of sampling (Fig. 3d).

For the biochemical variable $\mathrm{DBO}_{5}$, the highest value was recorded in the rainy season; dry season values were lower $(5.2 \mathrm{mg} / \mathrm{l}$ rainy and 3.1 $\mathrm{mg} / \mathrm{l}$ dry). For DQO we found low values in the rainy season and higher values in the dry season ( $80 \mathrm{mg} / \mathrm{l} \mathrm{O}_{2}$ rainy and $183.92 \mathrm{mg} / \mathrm{l} \mathrm{O}_{2}$ dry).

Total hardness was higher in the dry season (32 mg/l CaCO ${ }_{3}$ (dry) and $26 \mathrm{mg} / \mathrm{CaCO}_{3}$ (wet). Similar results were found for magnesium hardness: dry season $\left(20 \mathrm{mg} / \mathrm{l} \mathrm{CaCO}_{3}\right)$, rainy $(10 \mathrm{mg} / \mathrm{l}$ $\mathrm{CaCO}_{3}$ ). For calcium hardness the highest value was seen in the dry $\left(12 \mathrm{mg} / \mathrm{CaCO}_{3}\right)$ and the lowest in rainy season $\left(16 \mathrm{mg} / \mathrm{CaCO}_{3}\right)$. Generally concentrations of these variables were low. In contrast, alkalinity was high in the dry season $\left(64.28 \mathrm{mg} / \mathrm{l} \mathrm{CaCO}_{3}\right)$ and low in rainy $(28.14 \mathrm{mg} / \mathrm{l}$ $\mathrm{CaCO}_{3}$ ). The quantity of free $\mathrm{OH}$ in the ecosystem (Limnological acidity) varied significantly between seasons (Table 1). Suspended solids had higher concentrations in the dry season $(40 \mathrm{mg} /$ l), rainy $(5.0 \mathrm{mg} / \mathrm{l})$, as did total and dissolved solids ( $120 \mathrm{mg} / \mathrm{l}$ and $80 \mathrm{mg} / \mathrm{l}$ in rainy). Chlorine was high in the dry and low in the rainy season $(84.09$ $\mathrm{mg} / \mathrm{l}$ and $4.50 \mathrm{mg} / \mathrm{l})$. Turbidity had higher dry season values (129 FTU) as did suspended, dissolved and total solids in contrast to what was observed in rainy ( $<5$ FTU). And finally the values of $\mathrm{CO} 2$ were the same in both climatic seasons (Table 1).

Productivity and metabolism. Percentage of oxygen saturation in the dry season was on average $66.34 \%$ for the transparent and $67.26 \%$ for the dark bottle, the coefficients of variation were high for both bottles (32.69\% and 29.26\%); ANOVA didn't show significant differences between bottles $(\mathrm{F}=1.00 ; \mathrm{P}=0.517)$. In the rainy season this variable was on average $63.57 \%$ for the transparent and $64.18 \%$ for the dark bottle, the coefficient of variation were high $(18.05 \%$ and $17.98 \%)$; ANOVA didn't show significant differences between bottles $(\mathrm{F}=1,21 ; \mathrm{P}=0,483)$.

Regarding dissolved oxygen the analysis of variability didn't show significant differences between transparent and dark bottles $(\mathrm{F}=1.11$; $\mathrm{P}=0.3688$ ), nevertheless this variable showed noticeable decrease between $6: 00 \mathrm{~h}$ and $00: 00 \mathrm{~h}$ in the dry season (Fig. 3b). During the rainy season this variable was on average low in compari- 


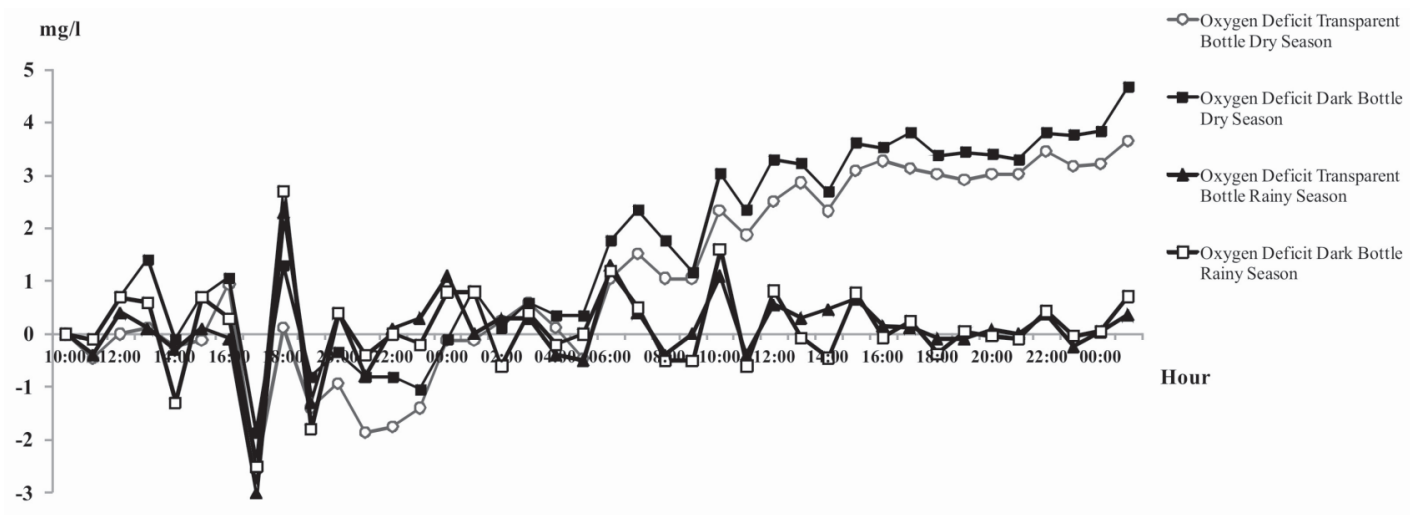

Fig. 4. Nictemeral compartment of oxygen deficit, for dry and rainy season in transparent and dark bottle, in Roble river, Upper Cauca, Colombia.

son with dry season and the dark bottle had low values in comparison with the transparent. This variable presented the same behavior between bottles and showed a decrease forthe second day (Fig. 3c), ANOVA did not detect significant differences between bottles $(\mathrm{F}=1.28 ; \mathrm{P}=0.2652)$. Statistic analyses of $\mathrm{pH}$ for both seasons indicated that there were no significant differences between bottles $(\mathrm{F}=0.89 ; \mathrm{P}=0.65$ dry and $\mathrm{F}=$ 1.16; $\mathrm{P}=0.31$ rainy). The transparent bottle showed an average of 7.75 with coefficient of variation $2.77 \%$, while the dark bottle showed an average of 7.68 and coefficient of variation $2.46 \%$, in both bottles values of coefficient variation were low.

Oxygen deficit in the dry season for both the transparent and dark bottles was high (1.057 and $1.58)$, as was the coefficient of variation $(167.19 \%$ and $110.71 \%$ ). Noticeable variations of oxygen deficit in transparent vs. dark bottles (Fig. 4) were recorded between 10:00 $\mathrm{h}$ and 15:00 $\mathrm{h}$ when a production of oxygen can be observed. Nevertheless near 17:00 h this was consumed in great quantity and that is evidently deficient in oxygen during the first day of sampling. It's important to note that on the second day of sampling there was no deficit of oxygen. In the same way values of this variable were higher in dark bottle than in the transparent in dial analysis. Similar results were obtained for the rainy season where the dark bottle had a higher oxygen deficit than the transparent $(0,10$ and 0,08$)$ and both bottles had high coefficients of variation $(100.78 \%$ and $100.86 \%$ ). For the rainy season oxygen consumption was high and production was low when compared to the dry season. ANOVA did not detect significant differences between bottles for either seasons $(\mathrm{F}=0.78 ; \mathrm{P}=0.57$ dry and $\mathrm{F}=1.08 ; \mathrm{P}=$ 0.46 rainy).
Using the previous data we calculated the lotic ecosystem metabolism following methods of Wetzel \& Likens (2000), where in dry season the re-aeration flux of oxygen was $3586.32 \mathrm{mg} / \mathrm{l}$, net metabolism was equal to -3585.81 and gross metabolism was equal to -3584.74 . Gross primary production (GPP) of the community was -3518.41 for transparent bottle and -3514.91 for dark bottle; in rainy season the re-aeration flux of oxygen was $1282.48 \mathrm{mg} / \mathrm{l}$, net metabolism was equal to -1281.64 and gross metabolism was equal to 1282.38. Gross community primary production (GPP) of was -1217.59 for the transparent bottle and -1209.19 for the dark.

Biological variables. The macroinvertebrate community included 8 orders and 32 families (Table 2). The highest abundance in both seasons was found for Ephemeroptera, family Tricorythidae $(55.6 \%$ in dry and $18.2 \%$ rainy). In the case of Coleoptera the most abundant family was Psephenidae (2.6\% in dry and $19.4 \%$ rainy). For the Trichoptera it was Hydropsychidae $(8.3 \%$ in dry and $3.5 \%$ rainy). The order with the lowest relative abundance was Plecoptera, family Perlidae (1.9\% and $5.1 \%$ for dry and rainy) (Table 2).

Generally, the alpha diversity index was low during both seasons but equity had a value of 0.68 for the rainy season but only 0.61 for the dry. This probably reflects the better ability to maintain the biotic community during higher water The Shannon Weiner ( $\left.\mathrm{H}^{\prime}\right)$ index and the Margalef index of diversity and dominance were both low (Table 6). Using the BMWP/Col classification system, the rainy season score was 198 and the dry 160 , which gives this river a class II, or «good» rating.

Phytoplankton. This community was represented with 3 divisions, 5 families and 40 gen- 
TABLE 2. Community of aquatic macroinvertebrates in the Roble river, Upper Cauca, Colombia. R.A. = Relative Abundance

\begin{tabular}{|c|c|c|c|c|c|c|}
\hline ORDER & FAMILY & GENERA & RAINY & $\mathrm{RA} \%$ & DRY & RA\% \\
\hline \multirow[t]{12}{*}{ Ephemeroptera } & \multirow[t]{4}{*}{ Baetidae } & Baetodes & 131 & 9.90 & 62 & 6.22 \\
\hline & & Baetis & 81 & 6.12 & 13 & 1.31 \\
\hline & & Moribaetis & 23 & 1.74 & 8 & 0.80 \\
\hline & & Dactylobaetis & 45 & 3.40 & 36 & 3.61 \\
\hline & \multirow{3}{*}{ Tricorythidae } & - & 61 & 4.61 & 0 & 0.00 \\
\hline & & Tricorythodes & 146 & 11.04 & 92 & 9.24 \\
\hline & & Leptohyphes & 20 & 1.51 & 448 & 44.98 \\
\hline & \multirow[t]{2}{*}{ Leptophlebiidae } & Thraulodes & 20 & 1.51 & 79 & 7.93 \\
\hline & & Traverella & 2 & 0.15 & 0 & 0.00 \\
\hline & Oligoneuriidae & Lachlania & 0 & 0.00 & 11 & 1.10 \\
\hline & \multirow[t]{2}{*}{ Ethyploaidae } & Compilacia & 0 & 0.00 & 1 & 0.10 \\
\hline & & Ephemerella & 0 & 0.00 & 1 & 0.10 \\
\hline \multirow[t]{8}{*}{ Coleoptera } & \multirow[t]{3}{*}{ Elmidae } & Cylloepus & 2 & 0.16 & 4 & 0.40 \\
\hline & & Macrelmis & 2 & 0.15 & 0 & 0.00 \\
\hline & & Disersus & 3 & 0.23 & 0 & 0.00 \\
\hline & \multirow[t]{4}{*}{ Psephenidae } & Psephenops & 242 & 18.29 & 25 & 2.51 \\
\hline & & Termanectus & 0 & 0.00 & 1 & 0.10 \\
\hline & & Promoresia & 0 & 0.00 & 1 & 0.10 \\
\hline & & Hydrochus & 0 & 0.00 & 1 & 0.10 \\
\hline & Ptilodactylidae & Anchitarsus & 5 & 0.38 & 2 & 0.20 \\
\hline \multirow[t]{13}{*}{ Trichoptera } & \multirow[t]{5}{*}{ Hydropsychidae } & Leptonema & 20 & 1.51 & 13 & 1.31 \\
\hline & & Smicridea & 24 & 1.81 & 68 & 6.83 \\
\hline & & Hyproptila & 0 & 0.00 & 1 & 0.10 \\
\hline & & Ochrotrichia & 0 & 0.00 & 1 & 0.10 \\
\hline & & Atopsyche & 0 & 0.00 & 1 & 0.10 \\
\hline & \multirow[t]{4}{*}{ Helicopsyche } & Helicopsyche & 5 & 0.38 & 0 & 0.00 \\
\hline & & Limneohilus & 0 & 0.00 & 2 & 0.20 \\
\hline & & Mystacides & 0 & 0.00 & 3 & 0.30 \\
\hline & & Borealis & 0 & 0.00 & 1 & 0.10 \\
\hline & Calamoceratidae & Phylloicus & 16 & 1.21 & 0 & 0.00 \\
\hline & Hydropsichidae & Leptonema & 2 & 0.15 & 0 & 0.00 \\
\hline & \multirow[t]{2}{*}{ Leptoceridae } & Nectopsyche & 3 & 0.23 & 0 & 0.00 \\
\hline & & Atanatolica & 4 & 0.30 & 0 & 0.00 \\
\hline \multirow[t]{12}{*}{ Odonata } & Libellulidae & Erythrodiplax & 4 & 0.30 & 0 & 0.00 \\
\hline & & Libelulido & 1 & 0.08 & 0 & 0.00 \\
\hline & & Macrothemis & 1 & 0.08 & 4 & 0.40 \\
\hline & & Dythemis & 83 & 6.27 & 14 & 1.41 \\
\hline & & Pantala & 0 & 0.00 & 4 & 0.40 \\
\hline & & Sympetrum & 0 & 0.00 & 3 & 0.30 \\
\hline & & Erythemis & 0 & 0.00 & 1 & 0.10 \\
\hline & & Berchmorhoga & 0 & 0.00 & 3 & 0.30 \\
\hline & & Espetugomphus & 0 & 0.00 & 5 & 0.50 \\
\hline & Caenagrionidae & Acanthogrion & 7 & 0.53 & 0 & 0.00 \\
\hline & Gomphidae & Progomphus & 2 & 0.15 & 0 & 0.00 \\
\hline & Calopterygidae & Hetaerina & 9 & 0.68 & 0 & 0.00 \\
\hline Diptera & Simuliidae & Simulium & 243 & 18.37 & 12 & 1.20 \\
\hline & Chironomidae & - & 3 & 0.23 & 1 & 0.10 \\
\hline & Psychodidae & Maruina & 1 & 0.08 & 0 & 0.00 \\
\hline & & Clognia & 1 & 0.08 & 0 & 0.00 \\
\hline & Empididae & Chelifera & 0 & 0.00 & 1 & 0.10 \\
\hline & & Hydrocanthus & 0 & 0.00 & 1 & 0.10 \\
\hline & & Anophelex & 0 & 0.00 & 1 & 0.10 \\
\hline & Blepharoceridae & Limonicola & 1 & 0.08 & 0 & 0.00 \\
\hline & Musadae & Limnophora & 1 & 0.08 & 0 & 0.00 \\
\hline Hemiptera & Veliidae & Microvelia & 0 & 0.00 & 14 & 1.41 \\
\hline & & Rhogovelia & 7 & 0.53 & 4 & 0.40 \\
\hline & & Striduvelia & 0 & 0.00 & 1 & 0.10 \\
\hline & Gerridae & Brachymetra & 19 & 1.44 & 1 & 0.10 \\
\hline & Naucoridae & Limnocoris & 2 & 0.15 & 0 & 0.00 \\
\hline Neuroptera & Corydalidae & Corydalus & 17 & 1.28 & 30 & 3.01 \\
\hline Plecoptera & Perlidae & Anacroneuria & 64 & 4.84 & 18 & 1.81 \\
\hline & & Patoperla & 0 & 0.00 & 3 & 0.10 \\
\hline & & Pteronoscela & 0 & 0.00 & 2 & 0.20 \\
\hline & 1323 & 100.00 & 996 & 100.00 & & \\
\hline
\end{tabular}


TABLE 3. Phytoplankton community of the Roble river, Upper Cauca, Colombia. R.A= Relative Abundance.

\begin{tabular}{|c|c|c|c|c|c|c|}
\hline DIVISION & FAMILY & GENERA & RAINY & $\mathrm{RA} \%$ & DRY & $\mathrm{RA} \%$ \\
\hline \multirow[t]{28}{*}{ Chlorophyta } & \multirow[t]{14}{*}{ Desmidiaceae } & Closterium & 8 & 0.06 & 38 & 0.15 \\
\hline & & Gonatozygon & 15 & 0.11 & 185 & 0.72 \\
\hline & & Microspora & 11 & 0.08 & 11 & 0.04 \\
\hline & & Mougeotia & 6 & 0.05 & 29 & 0.11 \\
\hline & & Netrium & 4 & 0.03 & 5 & 0.02 \\
\hline & & Nitzschia & 26 & 0.19 & 10 & 0.04 \\
\hline & & Mesotaenium & 16 & 0.12 & 0 & 0 \\
\hline & & Penium & 1 & 0.01 & 0 & 0 \\
\hline & & Docidium & 3 & 0.02 & 0 & 0 \\
\hline & & Staurastrum & 116 & 0.86 & 0 & 0 \\
\hline & & Spirotaenia & 1 & 0.01 & 0 & 0 \\
\hline & & Genicularia & 2 & 0.01 & 2 & 0.01 \\
\hline & & Pleurotaenium & 1 & 0.01 & 1 & 0.00 \\
\hline & & Ankistrodesmus & 3 & 0.02 & 2398 & 9.38 \\
\hline & \multirow[t]{6}{*}{ Chroococcaceae } & Chaetophora & 5 & 0.04 & 0 & 0 \\
\hline & & Characium & 2 & 0.01 & 0 & 0 \\
\hline & & Protococus & 1571 & 11.66 & 3162 & 12.37 \\
\hline & & Chrococcales & 9120 & 67.68 & 7581 & 29.65 \\
\hline & & Chroococcus & 0 & 0 & 112 & 0.44 \\
\hline & & Cladophora & 105 & 0.78 & 522 & 2.04 \\
\hline & \multirow[t]{8}{*}{ Chlorophyceae } & Cosmarium & 1 & 0.01 & 0 & 0 \\
\hline & & Kirchneriella & 4 & 0.03 & 0 & 0 \\
\hline & & Spirogyra & 4 & 0.03 & 9 & 0.04 \\
\hline & & Caetophora & 0 & 0 & 84 & 0.33 \\
\hline & & Crucigenia & 0 & 0 & 5383 & 21.05 \\
\hline & & Zygnema & 0 & 0 & 2 & 0.01 \\
\hline & & Ophiocytium & 0 & 0 & 454 & 1.78 \\
\hline & & Anabaena & 1 & 0.01 & 15 & 0.06 \\
\hline \multirow[t]{14}{*}{ Chrysophyta } & \multirow[t]{14}{*}{ Bacillariophyceae } & Ephithemia & 3 & 0.02 & 0 & 0 \\
\hline & & Navicula & 52 & 0.39 & 78 & 0.31 \\
\hline & & Stauroneis & 2 & 0.01 & 1 & 0.00 \\
\hline & & Stephanodiscus & 1 & 0.01 & 1 & 0.00 \\
\hline & & Synedra & 1 & 0.01 & 0 & 0 \\
\hline & & Tetrapedia & 2350 & 17.44 & 5377 & 21.03 \\
\hline & & Turbellaria & 12 & 0.09 & 10 & 0.04 \\
\hline & & Cyclotella & 0 & 0 & 4 & 0.02 \\
\hline & & Cymbella & 0 & 0 & 4 & 0.02 \\
\hline & & Diatoma & 0 & 0 & 19 & 0.07 \\
\hline & & Frustulia & 0 & 0 & 3 & 0.01 \\
\hline & & Gyrosigma & 0 & 0 & 2 & 0.01 \\
\hline & & Pinnularia & 0 & 0 & 4 & 0.02 \\
\hline & & Oscillatoria & 0 & 0 & 10 & 0.04 \\
\hline \multirow[t]{4}{*}{ Cyanophyta } & \multirow[t]{3}{*}{ Xanthophyceae } & Coelosphaerium & 33 & 0.24 & 6 & 0.02 \\
\hline & & Melosira & 0 & 0 & 3 & 0.01 \\
\hline & & Phormidium & 0 & 0 & 43 & 0.17 \\
\hline & TOTAL & 13475 & 100 & 25568 & 100 & \\
\hline
\end{tabular}

era (Table 3). We found $110 \mathrm{ind} . / \mathrm{ml}$ in the dry season but only $58 \mathrm{ind} . / \mathrm{ml}$ during high water. Divisions with more relative abundance were Chlorophyta (dry $78.18 \%$, rainy $81.82 \%$ ), next Chrysophyta (dry $21.58 \%$, rainy $17.97 \%$ ); and in last place the division Cyanophyta (dry 0.20\%, rainy $0.24 \%$ ). The most common families were Chroococcaceae (dry 51.83\%, rainy $79.41 \%$ ), Bacillariophyceae (dry $21.58 \%$, rainy $17.97 \%$ ), Chlorophyceae (dry $25.24 \%$, rainy $0.85 \%$ ), Desmidiaceae (dry $1.10 \%$, rainy $1.56 \%$ ) and Xanthophyceae (dry $0.20 \%$, rainy $0.24 \%$ ). The most abundant genera in both seasons were Chorococcales (dry $29.65 \%$, rainy $67.68 \%$ ), Tetrapedia (dry $21.03 \%$, rainy $17.44 \%$ ), Crucigenia (dry $21.05 \%$, rainy 0\%), and Ankistrodesmus (dry $9.38 \%$, rainy $0.02 \%$ ) (Table 3 ).

Zooplankton. Zooplankton was represented with 2 divisions and 6 genera (Table 4). There was $1 \mathrm{ind} . / \mathrm{ml}$ in dry season and $2 \mathrm{ind}$./ml in rainy. The most abundant divisions were Protozoa (dry $100 \%$, rainy $80 \%$ ) and Rotifera (rainy $20 \%$ ). The most common organisms present in both seasons were Paramecium (dry 50\%. rainy 10\%), next 
TABLE 4. Zooplankton community of the Roble river, Upper Cauca, Colombia. R.A = Relative Abundance.

\begin{tabular}{llllll}
\hline DIVISION & GENERA & RAINY & RA\% & DRY & RA\% \\
\hline Protozoos & Vorticella & 3 & 30 & 2 & 33.33 \\
& Euglena & 0 & 0 & 1 & 16.67 \\
& Stentor & 4 & 40 & 0 & 0 \\
\multirow{2}{*}{ Rotifera } & Paramecium & 1 & 10 & 3 & 50 \\
& Colurella & 1 & 10 & 0 & 0 \\
TOTAL & Testudinella & 1 & 10 & 0 & 0 \\
\hline
\end{tabular}

TABLE 5. Absolute and relative abundance (RA) of fish community in the Roble river, Upper Cauca, Colombia.

\begin{tabular}{lllll}
\hline TAXON & RAINY & RA\% & DRY & RA\% \\
\hline Astyanax fasciatus & 91 & 19.36 & 201 & 39.18 \\
Astyanax microlepis & 0 & 0 & 12 & 2.34 \\
Argopleura magdalenensis & 164 & 34.89 & 143 & 27.88 \\
Aequidens sp. & 0 & 0 & 1 & 0.19 \\
Bryconamericus caucanus & 30 & 6.38 & 55 & 10.72 \\
Brycon henni & 58 & 12.34 & 7 & 1.36 \\
Creagrutus brevipinnis & 67 & 14.26 & 56 & 10.92 \\
Creagrutus sp & 1 & 0.21 & 0 & 0 \\
Characidium caucanum & 3 & 0.64 & 10 & 1.95 \\
Chaetostoma fisheri & 21 & 4.47 & 1 & 0.19 \\
Hypostomus sp. & 27 & 5.74 & 13 & 2.53 \\
Hyphessobrycon ocasoensis & 0 & 0 & 4 & 0.78 \\
Imparfinis nemacheir & 1 & 0.21 & 0 & 0 \\
Lasciancistrus caucanus & 2 & 0.43 & 7 & 1.36 \\
Poecilia caucana & 2 & 0.43 & 1 & 0.19 \\
Rhamdia quelen & 0 & 0 & 1 & 0.19 \\
Roeboides dayi & 1 & 0.21 & 1 & 0.19 \\
Sturisomaticthys longianalis & 1 & 0.21 & 0 & 0 \\
Trichomycterus caliensis & 1 & 0.21 & 0 & 0 \\
TOTAL & & & & \\
& 470 & 100 & 513 & 100 \\
\hline
\end{tabular}

Vorticella (dry 33.33\%. rainy 30\%); and lastly Stentor (dry 0\%, rainy 40\%) (Table 4).

Alpha diversity for phytoplankton was low except for the index of dominance (rainy 0.70, dry 0.65), indicating that there are communities with exceptional numbers of individuals in ecosystem that occupy different niches. For this reason, equity (E) was low (dry 0.49 and 0.3 rainy). In the case of the Shannon Winner diversity in$\operatorname{dex}\left(\mathrm{H}^{\prime}\right)$ values were also low (dry 0.53 , rainy $0.48)$. Specific richness $(\mathrm{M})$ was about 0.20 for both seasons (Table 6).

For zooplankton only general indexes of diversity were evaluated for the rainy season. In the dry season no Rotifera were present. This index indicates that for this biotic community equity (E) was high with a value of 0.72 , while dominance (D) (0.64), diversity $\left(\mathrm{H}^{\prime}\right)(0.5)$ and specific richness $(0.43)$ were low.

Fishes. We recorded 19 species, with total of 470 individuals in the rainy season and 513 in the dry (Table 5). Species with higher relative abundance were: Argopleura magdalenensis (27.88\% in dry and $34.89 \%$ in rainy), Astyanax fasciatus $(39.18 \%$ in dry and $19.36 \%$ in rainy) and Creagrutus brevipinnis (10.92\% in dry and $14.22 \%$ in rainy). In general equity (E) was high (0.61 in dry and 0.68 in rainy), while dominance, diversity and specific riches were low for both climatic seasons.

Index of contamination for organic matter (ICOMO) with a value of 0.6 indicates that there is an average concentration of organic matter in this water body. Nevertheless, index of contami- 
TABLE 6. Alpha diversity of phytoplankton, zooplankton, macroinvertebrates and fish community, for two climatic seasons. H'= Shannon-Wiener Diversity. D = Simpson dominante. E = Pielou equity. M = Margalef riches

\begin{tabular}{|c|c|c|c|c|c|c|c|c|}
\hline \multirow[t]{2}{*}{ TAXON } & \multicolumn{4}{|c|}{ RAINY } & \multicolumn{4}{|c|}{ DRY } \\
\hline & $\mathrm{H}^{\prime}$ & $\mathrm{D}$ & M & $\mathrm{E}$ & $\mathrm{H}^{\prime}$ & $\mathrm{D}$ & M & $\mathrm{E}$ \\
\hline \multicolumn{9}{|c|}{ PHYTOPLANKTON } \\
\hline Chlorophyta & 0.59 & 0.70 & 2.14 & 0.19 & 1.58 & 0.25 & 1.71 & 0.54 \\
\hline Chrysophyta & 0.16 & 0.94 & 0.89 & 0.07 & 0.15 & 0.94 & 1.27 & 0.06 \\
\hline Cyanophyta & - & - & - & - & 0.92 & 0.51 & 0.72 & 0.66 \\
\hline General & 0.48 & 0.70 & 0.21 & - & 0.53 & 0.65 & 0.19 & 0.49 \\
\hline \multicolumn{9}{|l|}{ ZOOPLANKTON } \\
\hline Protozoos & 0.97 & 0.32 & 0.96 & 0.88 & 1.01 & 0.26 & 1.11 & 0.92 \\
\hline Rotiferos & - & - & - & - & - & - & - & - \\
\hline General & 0.50 & 0.64 & 0.43 & 0.72 & - & - & - & - \\
\hline \multicolumn{9}{|c|}{ MACROINVERTEBRATES } \\
\hline Ephemeroptera & 1.85 & 0.18 & 1.27 & 0.84 & 1.35 & 0.39 & 1.35 & 0.58 \\
\hline Coleoptera & 0.22 & 0.92 & 0.90 & 0.12 & 0.88 & 0.57 & 1.43 & 0.49 \\
\hline Trichoptera & 1.81 & 0.19 & 1.84 & 0.82 & 0.97 & 0.56 & 1.76 & 0.44 \\
\hline Odonata & 0.86 & 0.61 & 1.28 & 0.44 & 1.68 & 0.21 & 1.70 & 0.86 \\
\hline Diptera & 0.16 & 0.94 & 0.90 & 0.09 & 1.42 & 0.25 & 1.80 & 0.79 \\
\hline Hemiptera & 0.79 & 0.51 & 0.60 & 0.72 & 0.87 & 0.51 & 1.00 & 0.62 \\
\hline Neuroptera & - & - & - & - & 0.23 & 0.87 & 0.28 & 0.33 \\
\hline Plecoptera & - & - & - & - & 0.5 & 0.73 & 0.65 & 0.45 \\
\hline General & 1.64 & 0.24 & 0.97 & 0.79 & 0.99 & 0.57 & 1.01 & 0.47 \\
\hline \multicolumn{9}{|l|}{ FISHES } \\
\hline General & 1.84 & 0.20 & 2.27 & 0.68 & 1.67 & 0.25 & 2.24 & 0.61 \\
\hline
\end{tabular}

nation for suspended solids (ICOSUS) with value of 0.68 indicates good water quality.

\section{DISCUSSION}

Limnological studies of water quality are based on the principle that every type of aquatic ecosystem is associated with one specific community of organisms (Posada et al., 2000). The living communities that develop in aquatic ecosystems depend on specific physicochemical characteristics of the water and are noticeably modified when those conditions change (López et al., 1995). Dry season physicochemical variables recorded in the lower Roble river showed high coefficients of variation for relative humidity, percentage of oxygen saturation, dissolved oxygen and oxygen deficit in transparent and dark bottles. This can be attributed to environmental fluctuations that were high for the dry season and also, the discharge of municipal residual waters about three $\mathrm{km}$ above the sampling site, which permitting some auto-purification of the system (Dodds, 2006; 2007). The high coefficient of variation for oxygen deficit can be explained if we take into account that it's closely related with the trophic state of the water body and is easily influenced by the day-night interface where a change from an autotrophic state to a heterotrophic (and vice versa) can be observed according to Dodds \& Cole (2007).

Bimodal variation of water and ambient temperature is attributed to a high specific energy of water and fluctuations from the day-night interface (Roldan, 1992). Relative humidity in this analysis had more fluctuation in the dry season because it was conditioned by environmental factors such as temperature that vary considerably during this season. Conductivity values obtained for both climatic seasons did not show noticeable differences; nevertheless it's important to take into account existing relationship between this variable and $\mathrm{pH}$. According to Roldan (1992) $\mathrm{pH}$ influences conductivity with the quantity of present free ions, atypical values of this variable are explained with the presence of sporadic precipitation in dry season which alternate ecosystem because of allochthonous material influx. Moreover, increase of discharge input decreased the concentration of dissolved solids dilution per cubic meter enabling in this way process of mineralization of ecosystem (Allan 1995; Wetzel 2001; Toro et al., 2002). Other factors such as river vegetation, land use and various sewage 
contaminants influence on the values of obtained conductivity in this aquatic ecosystem (Toro et $a l ., 2002)$.

Usually, higher levels of dissolved oxygen indicate better water quality (Roldan, 1992). For the Roble river, the average of dissolved oxygen values were found to be at optimal levels. Nevertheless, lower oxygen concentrations possibly may indicate that higher turbidity in the rainy season in the upper part of the river inhibits light penetration and autotrophic activity. Higher concentrations dissolved and particulate organic material flushed out during the rainy season probably caused increased oxygen demand for mineralization that resulted in lower overall values for dissolved oxygen at that time. Percent oxygen saturation indicates that for the first day of sampling light heterotrophic conditions were present (Urrego \& Ramírez, 2000). DBO was low and DBQ high for dry season, indicating possible eutrophication due to the constant addition of nutrients to this water body in the form of allochthonous material that enables biological communities that process organic material to become established, which may in turn have affected acidity which was observed to have lower values than alkalinity.

Metabolism of aquatic ecosystem refers to the processes of production, consumption and decomposition (Roldan, 1992). They normally occur simultaneously in balanced and synchronized form, but when the balance is disturbed due to contamination by organic matter, processes of decomposition and photosynthesis are accelerated in the day-night cycle causing unbalance in the ecosystem that affects the ecosystem's stability and communities that live there (Roldan, 1992). Because of this, trophic state in water bodies can be determined from metabolism activity (Dodds, 2006). Following the methodology of transparent and dark bottle, it can be observed that the ecosystem is heterotrophic.

The macroinvertebrate community found coincides with that reported by García-Alzate ., (2007). The index of alpha diversity calculated for this river showed that Diptera had high dominance values associated with the trophic conditions of the water body. Diptera larvae prefer productive ecosystems with good nutrient availability. Ephemeroptera showed a higher index of diversity because some families have some tolerance to contamination (Roldan, 2003).

In the case of phytoplankton various families of the Chlorophyta division were present that are characteristic of productive environments (Roldan, 1992). But we also found Chrorococcales, division Chrysophyta, which are usually common in low productivity environments. The occurrence of Cyanophyta indicated increase nutrient input that favors proliferation of these algal types (González et al., 2004). The presence of algae that usually indicate very different trophic conditions let us to classify the lower Roble river as oligo-trophic, with a tendency to eutrophication.

Regarding fishes, 19 species were recorded, dominating the Characidae. According to GarcíaAlzate et al. (2007), the species found are indicators of oligotrophic or little intervened systems, although some have a wide range of distribution, and are somewhat tolerant of contamination and are often found in this type of transitional environment.

Taking in to account information from physicochemical and biological parameters together with the index of contamination for organic matter (ICOMO), this river is moderately contaminated with organic matter, from domestic and industrial waste, and discharge of livestock, in coincidence with what was reported by Rivera \& Mejia (2005). The index of contamination for suspended solids (ICOSUS) indicated that water quality was «good» possibly because auto purification occurred above our sampling site. These results coincide with that of BMWP, also stating that water quality was "good». It can be concluded that the lower Roble river has a heterotrophic allochthonous trophic state, and is oligotrophic with a tendency to eutrophication.

\section{ACKNOWLEDGMENTS}

Financial support was received from the Universidad of Quindío, Vicerrectoria of Investigations (Project 357) and Program of Biology. We thank the biology students of the limnology course program of Biology for their assistance in the field work.

\section{BIBLIOGRAPHY}

APHA, American Public Health Association, American Waterworks, Association (AWWA), Water Pollution Control Federation (WPCF). 1998. Standard methods for examination of water and sewage and wastewater. 20a. Ed. New York.

Alba-Tercedor, J. 1996. Macroinvertebrados acuáticos y calidad de las aguas de los ríos. IV Simposio del Agua en Andalucía (SIAGA), II: 203-213.

Allan, J.D. 1995. Stream Ecology. Structure and Function of Running Waters. Chapman and Hall: 97 p.

Bicudo, E. \& R. Bicudo. 1970. Algas de aguas contentails Brasileiras. São Paulo: Fundação Brasileira Para O Desenvolvimento Do Ensino De Ciêcias. $157 \mathrm{p}$.

Caicedo, O. \& J. Palacio. 1998. Los macroinvertebrados bentónicos y la contaminación orgánica en la 
quebrada la mosca (Guarne, Antioquia, Colombia). Rev. Actual. Biol. 20(69): 61-73.

Dodds, W. 2006. Eutrophication and trophic state in rivers and streams. Limnol \& Ocean. 51: 671 - 680. 2007. Trophic state, eutrophication and nutrient criteria in stream. Trends in ecology and evolution. 22: 669-676.

Dodds, W. \& J.J. Cole. 2007. Expanding the concept of trophic state in aquatic ecosystems: It's not just the autotrophs. Aqua. Scien. 69: 427-439.

García-Alzate, C. \& C. Román-Valencia. 2008. Una nueva especie de Hyphessobrycon (Pisces: Characidae) grupo heterorhabdus (Géry, 1977) para el Alto Río Cauca, Colombia. Animal biodiversity and Conservation. 31(2): 11-23.

García-Alzate, C., C. Román-Valencia, J. Vanegas-Ríos \& D. Arcila-Mesa. 2007. Análisis fisicoquímico y biológico comparado en dos Quebradas de alta montaña neotropical. Revista de Investigaciones de la Universidad del Quindio. 17: 57-80.

González, E., M. Ortiz, C. Peña \& M. Matos. 2004. Fitoplancton de un embalse tropical hipertrófico (Pao-Cachinche, Venezuela): abundancia, biomasa y producción primaria. Interciencia. 29: 548-554.

Kudo, R. 1966. Protozologia. México, D.F. 345 p.

Lampert, W. \& U. Sommer. 1997. Limnoecology: The ecology of Lakes and Streams. Nueva York: Oxford University Press; 382p.

Lackey, J. 1956. Zooflagelados. En: Y. Ward Whipple, (ed.), Freshwater Biology. New York: Edimmsem. 190-231.

López, F.M., A. Pujante, V. Ribarrocha \& G. Tapia. 1995. Macroinvertebrados y calidad de las aguas de la red de la provincia de Castellón. Ecol. 9: 71-108.

Needham, J. \& P. Needham. 1978. Guía para el estudio de los seres vivos de las aguas dulces. Barcelona: Reverte, S.A. 153 p.

Pérez-López, F.J. \& F.M. Sola-Fernández. 1993. DIVERS: Programa para el cálculo de los índices de diversidad. [programa informático en línea]. Available from Internet: http://perso.wanadoo.es/ jp-l/descargas.htm

Posada G., P. Roldan, R. Ramírez \& J. John. 2000. Caracterización fisicoquímica y biológica de la calidad de aguas de la cuenca de la quebrada Piedras Blancas, Antioquia, Colombia. Rev. Biol. Trop. 48: 59-70.

Posada-García, J. \& G. Roldán-Pérez. 2003. Clave ilustrada y diversidad de las larvas de Trichoptera en el Nor-Occidente de Colombia. Caldasia. 25: 75192.

Rivera, J. \& D. Mejía. 2005. Estudio de algunos índices de calidad del agua para las épocas de altas y bajas lluvias en La Quebrada la Jaramilla. La Tebaida Quindío, Colombia. Revista de Investigaciones Universidad del Quindío. 15: 45-54.

Rodríguez, E., M. Hubbard \& W. Peters. 1992. Clave para ninfas y adultos de las familias y Géneros de Ephemeroptera (Insecta) sudamericanos. Biología acuática. 16: 8-15.
Roldán, G. 1992. Fundamentos de limnología Neotropical. Fen-Universidad de Antioquia, Medellín. 529 p.

- 1996. Guía para el estudio de los Macroinvertebrados acuáticos del Departamento de Antioquia. Bogotá: Editorial FEN- conciencias. $217 \mathrm{p}$.

2003. Bioindicación de la calidad de agua en Colombia, uso del método BMWP modificado para Colombia. Editorial Universidad de Antioquia. 170 p.

Roldán G. \& J. Ramírez. 2008. Fundamentos de limnología neotropical. Segunda edición. Editorial Universidad de Antioquia. Medellín, 440 p.

Román-Valencia, C. 1995. Lista anotada de los peces en la cuenca del Rio La Vieja, Alto Cauca, Colombia. Bol. Ecotrópica. 29: 11-22.

- 2003. Sistemática de las especies Colombianas de Bryconamericus (Characiformes: Characidae). Dahlia. 6: 17-58.

Román-Valencia, C., J. Cadavid, J. Vanegas-Ríos \& D. Arcila-Mesa. 2005. Análisis de algunas variables físicas, químicas y biológicas en tres Quebradas de la cuenca Alta del Río Cauca, Colombia. Revista de investigaciones de la Universidad del Quindio. 15: 83-96.

Román-Valencia, C. \& R. Ruiz-Calderón. 2007. Una nueva especie de pez del genero Hemibrycon (Characiformes: Characidae) del Alto Río Atrato, Noroccidente de Colombia. Caldasia. 29: 75-85.

Ruiz-Calderón, R. \& C. Román-Valencia. 2006. Osteología de Astyanax aurocaudatus Eigennman, 1913 (Pisces: Characidae), con notas de la validez de Carlastyanax, Gery, 1972. Animal Biodiversity and Conservation, 29: 49-51.

Sierra, O.R., J.J. Ramirez \& O.F. Marin. 2004. Dinámica temporal de la comunidad fitoplanctonica y variables físicas y químicas asociadas al lago Santander (Río Negro, Antioquia, Colombia). Revista Actualidades Biológicas, 26: 30-38.

Toro, M., S. Robles, J. Avilés, C. Nuñoz, S. Vivas, N. Bonada, N. Prat, J.C. Alba-Tercedor, J. Guerrero, P. Jáimez-Cuéllar, J. Moreno, G. Moyá, M. Suárez, M. Vidal-Abarca, M. Álvarez, \& I. Pardo. 2002. Calidad de las aguas de los ríos mediterráneos del proyecto GUADALMED características físicoquímicas. Limnética. 21: 63-75.

Uhlerkovich, A. \& G. Schmidt. 1974. Pheyplanktantaxo in dem zentralamazonishen schwemmlandsee lago do Castanho. Amazoniana. 2: 3-283.

Urrego, A. \& J. Ramírez. 2000. Cambios diurnos de variables físicas y químicas en la zona de ritral del rio Medellín. Caldasia. 22: 127-141.

Viña, V. \& G. Ramírez. 1998. Limnológica Colombiana, aportes para su conocimiento y estadísticas de análisis. Bogotá D.C: B.P. Exploration Company. $154 \mathrm{p}$.

Wetzel, R. G. 2001. Limnology. Lake and river ecosystems. Third edition. Academic Press. 429 p.

Wetzel, R. \& G. Likens. 2000. Limnological analyses, 3 ed. New York: Springer-Verlag. 429p. 